either in the British Museum or in the private collection of Professor Edward G. Browne.

In his later years Edwards was much afflicted with rheumatism and worked under difficulties.

\title{
Colonel D. M. F. Hoysted (1874-1945)
}

As his second Christian name indicates, Desmond Murree Fitzgerald Hoysted was born at Murree in the Panjab, his father, who later became Surgeon-General, Madras Presidency, Indian Army, being then stationed in India. Educated at Rugby School and the Royal Military Academy, he was appointed to the Royal Engineers, and promoted in 1894 Lieutenant in the 26th Field Company, R.E. Serving throughout the South African War of 1899-1902, he took part in, amongst others, the engagements at Coleskop, Colesberg, Modder River, Paardeburg, Bloemfontein, Abraham's Kraal, Nicholson's Nek, the capture of Pretoria, and Vereiniging, receiving the Queen's Medal with three clasps and the King's Medal with two clasps. Returning home from Natal in 1904 he served on the Staff as Division Officer, R.E., and acting C.R.E. Dublin District. He was then posted to the Alexandria Garrison of the British Army of Occupation in Egypt, where he served until 1914, when he was appointed Staff Officer, London District. It was during this long service in Egypt that he acquired a taste for Oriental subjects. On the outbreak of World War I he went to France, and was the second man of the B.E.F. to land at Le Havre on 6th August, 1914. In command of the 9th Field Company R.E. he fought on the Marne and the Aisne, at Armentières, Ploegsteert Wood, and the Ypres Salient, receiving the 1914 (Mons) Star. In September, 1915, he was appointed C.R.E. 22nd Infantry Division, Serbian Expeditionary Force, and took part in the actions at Salonika, the Struma Valley, and Lake Doiran, and in Bulgaria, being mentioned in dispatches on three occasions, and being awarded the D.S.O. for special service in 1916. In 1917 he was invalided home, but was able to carry on the duties of Chief Instructor of Fortifications until 1918, when he returned to France as C.R.E. 3rd Army Defence Lines, B.E.F. After the war he held the appointments of Instructor, Senior Officers' School, Woking, and of C.R.E. 
in different areas till 1926, when he became Chief Technical Examiner of R.E. Works, War Office. In recognition of his valuable services in this last capacity he was awarded the C.B.E. in 1930. In that year he retired, and took up the post of Secretary, Royal Asiatic Society, which he held for ten years until 1940, when war conditions necessitated drastic reduction of staff. World War II having meanwhile begun he at once offered his services to Government, and he was employed in the Research and Experimental Branch of the Ministry of Home Security. He also served as an A.R.P. Warden.

Hoysted's career in the Army was both varied and distinguished, but his innate modesty made him indisposed to talk about the many campaigns in which he had served. When, however, he could be induced to reveal some of his experiences his descriptions had enhanced value and interest.

To his work as Secretary, R.A.S., he devoted himself with characteristic industry and zeal, always anxious to promote the interests of the Society. Though his health showed signs of impairment towards the end of his term of office, he did not relax in punctual attention to his duties. Ever courteous and kindly, he won the regard of all who worked with or under him.

$\mathrm{He}$ married his cousin, Sybil Christine Hoysted, daughter of Lieut.-Col. I. Hoysted. A devoted husband, after her death in December, 1942, his health seemed to deteriorate rapidly. Extra work in the house and garden done, in spite of a doctor's warning, to help his daughters in their heavy duties imposed too great a strain on his weak heart, and he passed away on 3rd October last. He leaves two sons and two daughters.

C. E. A. W. OLdham. 